\title{
Response Surface Methodology for Extraction of Curcumin from Turmeric and Piperine from Black Pepper
}

\author{
Yücel Başpınar ${ }^{*}$, Mehmet Üstündaş², Oğuz Bayraktar ${ }^{3}$, Canfeza Sezgin ${ }^{4}$ \\ 1* Ege University, Faculty of Pharmacy, Department of Pharmaceutical Biotechnology, 35100 Bornova- \\ Izmir, Turkey, Tel: +902323112532, Faks: +902323885258, *yucel.baspinar@ege.edu.tr \\ 2,3 Ege University, Faculty of Engineering, Department of Chemical Engineering, , 35100 Bornova-Izmir, \\ Turkey, \\ mehmetustundas@gmail.com, oguzbayraktar70@gmail.com \\ ${ }^{4}$ Ege University, Faculty of Medicine, Medical Oncology, 35100 Bornova-Izmir, Turkey, \\ canfezasezgin@gmail.com \\ *corresponding author
}

Received: 22 February 2017

Accepted: 24 July 2017

DOI: $10.18466 /$ cbayarfbe.339351

\begin{abstract}
Considering that approximately a third of all drugs currently on the market is derived from natural products, curcumin attracted attention due to its anticancer, antioxidative, antiinflammatory and antimicrobial properties. Unfortunately, its low solubility and depending on that a poor bioavailability are limiting factors for its clinical application. It was shown that the administration of curcumin with piperin, the main component of black pepper, increased the bioavailability of curcumin. In addition, piperine increased the plasma concentration and delayed the elimination of drugs like phenytoin and rifampin, and has antiinflammatory and antifungal properties among others. Considering the literature has shown that for extracting curcumin and piperine, respectively, Soxhlet, microwave-assisted extraction, supercritical carbon dioxide extraction and concentional extraction with ethanol as solvent were used among others. According to the concentional extraction of curcumin with ethanol important parameter like the ethanol concentration was not investigated. In addition the maximum extraction time in this case was only 50 minutes, too short in our opinion. Due to these facts the optimum extraction parameters for the conventional extraction of curcumin from turmeric and of piperine from black pepper, respectively, were investigted in this study, with respect to extraction time of 7-21 hours, ethanol concentration of 10-90\% and drug to solvent ratio of 1:10-1:30. Response surface methodology was used as a tool to determine the optimum conditions for the extraction of curcumin and piperine, with help of an experimental design, central composite design. The ideal parameter for this conventional extraction of curcumin from turmeric and of piperine from black pepper, respectively, were an extraction time of 15 hours, an ethanol concentration of $70 \%(\mathrm{v} / \mathrm{v})$ and a drug to solvent ratio of 1:20.
\end{abstract}

Key words: Black Pepper, Curcumin , Extraction, Piperine, Response Surface Methodology, Turmeric.

\section{Introduction}

Approximately a third of all drugs currently on the market is derived from natural products [1]. The active compound of turmeric (Curcuma longa), curcumin (C) [1,7-bis(4-hydroxy-3-methoxyphenyl)-1,6-heptadi- ene3,5-dione] has antioxidative [2, 3], anticancer [4, 5], antiinflammatory [6, 7] and antimicrobial [8, 9] properties. A serious disadvantage of $\mathrm{C}$ is unfortunately its low solubility and poor bioavailability [9, 10]. This combination of low solubility and poor bioavailability negatively affects its biological efficacy [11] and limits its clinical application. The rapid degradation under neutral or alkaline $\mathrm{pH}$ conditions or when exposed to light is another serious disadvantage of $\mathrm{C}$ [12]. The orange-yellow powder $\mathrm{C}$ is obtained by solvent extraction of ground rhizomes of turmeric.

It is known that co-administration of $\mathrm{C}$ with piperin $(\mathrm{P})$ ((2E,4E)-5-(1,3-benzodioxol-5-yl)-1-(1-piperidinyl)-

2,4-pentadien-1-one) is a useful strategy to increase the bioavailability of C $[13,14]$. It was postulated that $P$ acts as an apolar molecule forming an apolar complex with drugs and helps to modulate membrane dynamics and the permeability across barriers [15]. P has attracted attention for its antifungal [16], antidiarrhoeal [17], antiinflammatory [18] and 5-lipoxygenase and cyclooxygenase-1 inhibitory activities [19]. In addition, it serves as a positive GABA-A receptor [20, 21]. Several phytochemicals like $\mathrm{P}$, the major component of black 
pepper (Piper nigrum L.), have been shown to have an activity against $\mathrm{P}$ glycoprotein-mediated efflux [22, 23]. $\mathrm{P}$ increased the plasma concentration and delayed the elimination of phenytoin [24] and rifampin [25], both Pgp substrates [26, 27]. In addition, the P-gp-mediated transport of digoxin and cyclosporine in the Caco-2 cell monolayers was inhibited by P [28].

The available techniques for the extraction of $\mathrm{C}$ are versatile and consist of Soxhlet, microwave-assisted extraction, supercritical carbon dioxide extraction and ultrasonic assisted extraction among others. Soxhlet extraction is time consuming, too laborious and makes the use of bulk amount of organic solvents [29-34]. Several other methods like solid-liquid extraction, aqueous alkaline extraction, extraction with vegetable oils, extraction with aqueous alkanol solutions and supercritical fluid extraction have been developed to extract efficiently compounds from aromatic plants [35]. There are several studies in the literature concerning the extraction of $\mathrm{C}$ using different techniques and solvents. In a study of conventionally extraction of $\mathrm{C}$ by solvent extraction the extraction temperature $\left(50-90^{\circ} \mathrm{C}\right)$, the particle size of the turmeric powder $(0.42-0.85 \mathrm{~mm})$, the mixing time (10 - 50 minutes) and solvent to meal ratio (10 - 50) were tested be transferring turmeric and a measured amount of absolute alcohol to a flask, which was stirred and heated using a water bath at a selected temperature for a predetermined time. The optimum conditions for the $\mathrm{C}$ extraction in this study were $60^{\circ} \mathrm{C}$ temperature, $0.42 \mathrm{~mm}$ particle size, $30 \mathrm{~min}$ mixing time and solvent (ethanol) to meal ratio of 50 [36]. For investigating the recovery of $\mathrm{C}$, extracted from turmeric, Microwave-assisted extraction was compared to conventional heat-assisted extraction by varying the solvent concentration $(0-100 \%, \quad \mathrm{v} / \mathrm{v})$, extraction temperature (30-130 ${ }^{\circ} \mathrm{C}$ ) and extraction time (0-20 min). Microwave-assisted extraction was performed with acetone, chloroform, ethanol, methanol, and methylene chloride. It could be shown that the extraction of $\mathrm{C}$ from turmeric was greatly influenced by the solvent concentration. After adding $20 \%$ water to methanol or ethanol, respectively, the highest extraction yield of $\mathrm{C}$ among other solvent mixtures tested was obtained. Increasing the water concentration in the solvent mixtures resulted in a decreased extraction yield of C. There was not a significant difference between the extraction results of $80 \%(\mathrm{v} / \mathrm{v})$ aqueous methanol and $80 \%(\mathrm{v} / \mathrm{v})$ aqueous ethanol solutions. C could have an affinity to both polar and non-polar solvents through hydrogen-bonding interactions, although it is a hydrophobic polyphenol having low polarity and low water-solubility [37], leading to formation of H-bonds with solvents like water, methanol and ethanol. The optimum temperature for the extraction of $\mathrm{C}$ from turmeric was $80{ }^{\circ} \mathrm{C}$ due to the fact that a probably degradation occurred at temperatures higher than $80{ }^{\circ} \mathrm{C}$ $[38,39]$. The extraction of $\mathrm{C}$ was increased with an increase in extraction time, reached the highest level in 5 min and did not change significantly after this point [40]. In another study $\mathrm{C}$ was extracted with polar solvents like isopropyl alcohol, ethyl acetate, acetone by cold and hot extraction. The cold extraction procedure resulted in the higher yield of C [41].

In order to determine the $\mathrm{C}$ content in turmeric Soxhlet extraction was used. The investigated parameters were the solvents ethanol (96\%, v/v) and n-hexane, the temperature (25, 40 and $\left.55^{\circ} \mathrm{C}\right)$, the liquid to solid ratio (20, 30 and $40 \mathrm{ml} / \mathrm{g}$ ) and the extraction time (1, 2.5 and 4 hours) with the help of Box-Behnken Design. It was observed that ethanol was more efficient than n-hexane. The optimum conditions for the $\mathrm{C}$ extraction were found as a temperature of $33^{\circ} \mathrm{C}$, a liquid solid ratio of $24 \mathrm{~mL} / \mathrm{g}$ and an extraction time of $94 \mathrm{~min}$ [42].

$\mathrm{P}$ is generally isolated from black pepper using volatile organic solvents such as ethanol, toluene or chlorinated hydrocarbons [43, 44]. Using surface-active ionic liquids- aqueous micellar solutions for the extraction of $\mathrm{P}$ from black pepper resulted in a strong correlation between extraction yield and the critical micelle concentration of the respective ionic liquid [45]. Conventionally extraction of $\mathrm{P}$ is performed by solvent extraction using aliphatic and chlorinated Hydrocarbons like acetone and ethanol for periods of 16- $24 \mathrm{~h}$ [43]. It was reported that $\mathrm{P}$ was extracted using supercritical carbon dioxide or carbon dioxide + ethanol mixtures [4648]. In a further study the solvents ethanol, dichloromethane, toluene, heptane and petroleum ether were used for microwave-assisted extraction of $\mathrm{P}$ from Piper nigrum resulted in that $\mathrm{P}$ was largely extracted in the nonpolar solvents such as petroleum ether [49]. The same authors used in a further study the aromatic sulfonate hydrotropes sodium xylene sulfonate, sodium cumene sulfonate, sodium $p$-toluene sulfonate, $n$-Butyl benzene and sodium butyl monoglycol sulfate for the extraction of $\mathrm{P}$ by a continuous Soxhlet extraction with petroleum ether for $48 \mathrm{~h}$. Structural changes in the biomatrix of Piper nigrum caused by the solvents lead to an enhanced extraction rate [50]. The combination of the hydrotrope butyl benzene sulfonate with the surfactant sodium dodecyl sulfate in aqueous solutions was investigated for the extraction of P. It was found that beyond the critical micelle concentration of the surfactant the extraction of $\mathrm{P}$ increased with an increased concentration of the aqueous SDS solution. The use of butyl benzene sulfonate did not resulted in a significant improved extraction of P [51].

Considering all the versatile techniques and solvents used for the extraction of curcumin and piperine, respectively three crucial decisions had to be made for our study: 1 . Choice of extraction technique2. Choice of proper extraction solvent and 3. Choice of effective extraction parameters. 
In our case conventional solvent extraction technique was preferred by stirring the turmeric powder and black pepper powder in separate glass beakers for the extraction of both $\mathrm{C}$ and $\mathrm{P}$, respectively, due to the fact of being an easy procedure. The literature investigations have shown that for such a conventional extraction like intended here, ethanol was an appropriate solvent. In a study [36] the extraction temperature, the particle size, the extraction time and solvent to solid ratio were tested for the extraction of $\mathrm{C}$. In the present study the extraction temperature was not taken into consideration for two reasons, namely the facts that temperatures of higher than $80^{\circ} \mathrm{C}$ are disadvantageous for the extraction of $\mathrm{C}$ and the fact that cold extraction procedure results in a higher yield of C [41].

To the best of our knowledge there is no report in the literature about the conventional extraction of $\mathrm{P}$ with detailed investigation of the extraction parameters.

Due to these facts it was decided to investigate new parameter like a much longer extraction time of 7-21 hours and ethanol concentrations of 10-90 \%, which were not tested before. Furthermore, the drug to solvent ratio as an important parameter in extraction was added to the parameters intended to be investigated.

Response surface methodology (RSM) was used as a tool to determine the optimum conditions for the extraction of $\mathrm{C}$ from turmeric and of $\mathrm{P}$ from black pepper. RSM is effective for optimizing the process when many factors and interactions affect the desired response [52]. Using a minimum of resources and quantitative data from an appropriate experimental design to determine and simultaneously solve a multivariate equation RSM is an effective statistical method [53]. RSM uses an experimental design likes central composite design (CCD) to fit an empirical model. A CCD combined with a full second-order polynomial model, is very powerful to provides an adequate representation of most continuous response surfaces over a relatively broad factor domain (Deming, 1990). A CCD including independent variables like extraction time, ethanol concentration and drug to solvent ratio was used. Selected response (dependent variable) which evaluates the extraction process was yield of $\mathrm{C}$ and $\mathrm{P}$, respectively.

Due to these facts it was aimed in this study to determine the optimum extraction conditions of $\mathrm{C}$ from turmeric and $\mathrm{P}$ from black pepper, respectively. For that purpose, $\mathrm{C}$ and $\mathrm{P}$ were extracted by varying the extraction time, ethanol concentration and drug to solvent ratio. Subsequently, the $\mathrm{C}$ and $\mathrm{P}$ concentrations were simultaneously analysed with HPLC in order to determine out the optimum extraction time, ethanol concentration and drug to solvent ratio.

\section{Materials and Methods}

\section{Materials}

The black pepper powder and turmeric powder were supplied from India. Ethanol with analytical grade was purchased from Merck (Merck, Darmstadt, Germany) and the reference substances of $\mathrm{C}$ and $\mathrm{P}$ were purchased from Sigma-Aldrich (Sigma, St.Louis, MO, USA).

\subsection{Analyses of curcumin and piperine with HPLC}

The concentrations of $\mathrm{C}$ (Figure 1 ) and $\mathrm{P}$ (Figure 2) were analysed with HPLC (Thermo Scientific Ultimate 3000), equipped with a pump and a diode array detector at 262 $\mathrm{nm}$ at a column temperature of $33^{\circ} \mathrm{C}$. The mobile phase consisted of a mixture of $0.1 \%$ phosphoric acid and acetonitrile (45:55 \%, v/v), and the flow rate was set at $0.8 \mathrm{~mL} /$ minute. A C18 column Acclaim $^{\circledR} 120$ (Thermo Scientific $120 \AA \mathrm{C} 183 \mu \mathrm{m} 4.6$ x $150 \mathrm{~mm}$ ) was used, and the injection volume was $20 \mu \mathrm{L}$. HPLC assay validation was performed five times a day for 5 consecutive days at a $\mathrm{C}$ and $\mathrm{P}$ concentration range 0.0625-0.03125-0.01562$0.00675 \mathrm{mg} / \mathrm{ml}$, respectively. This method was modified after [54].<smiles>[R]c1cc(/C=C/C(=O)CC(=O)/C=C/c2ccc(/C=C/C(O)CC(=O)/C=C/c3ccc(O)c([R])c3)c([R])c2)ccc1O</smiles>

\begin{tabular}{l|c|c} 
& $\mathbf{R}$ & $\mathbf{R}^{\prime}$ \\
\hline Curcumin & $\mathbf{O C H}_{3}$ & $\mathbf{O C H}_{3}$ \\
\hline Demethoxy-curcumin & $\mathbf{H}$ & $\mathbf{O C H}_{3}$ \\
\hline Bis-Demethoxy-curcumin & $\mathbf{H}$ & $\mathbf{H}$
\end{tabular}

Figure 1. The chemical structure of curcumin (keto and enol form), desmethoxy-curcumin and bis-desmethoxycurcumin. 
<smiles>O=C(/C=C/C=C/c1ccc2c(c1)OCO2)N1CCCCC1</smiles>

Figure 2. The chemical structure of piperine.

\subsection{Extraction experiments for turmeric and black pepper}

\subsubsection{Curcumin and piperine extraction}

The aim of the extraction experiments was to estimate the best possible yield of $\mathrm{C}$ from turmeric and of $\mathrm{P}$ from black pepper, respectively. Turmeric and black pepper were extracted with selected 20 combinations of parameter (RSM independent variables) such as ethanol concentration (10, 50 and $90 \%$ ), extraction time (7, 14 and 21 hours) and drug/solvent ratio (1:10; 1:20 and 1:30 v/w) (Table 1). Turmeric and black pepper powder (each $1 \mathrm{~g}$ ) were extracted with a magnetic stirrer at $400 \mathrm{rpm}$ in a glass beaker at room temperature. The slurry was filtered through a $0.45 \mu \mathrm{m}$ polytetrafluorethylene (PTFE) filter (Sartorius, Göttingen, Germany) prior to analysis of the $\mathrm{C}$ and $\mathrm{P}$ content, respectively, with HPLC. All the experiments were carried out in triplicate.

\subsubsection{Experimental design}

For determining the influence of three independent variables and the optimum conditions of $\mathrm{C}$ and $\mathrm{P}$ isolation, a RSM with a CCD was used. The process variables were defined from published data [36, 41, 42, $55,56]$. The response function investigated was $\mathrm{C}$ extraction yield $\mathrm{y}=\mathrm{mg}$ of curcumin/ $\mathrm{g}$ turmeric powder and $\mathrm{Y}=\mathrm{mg}$ of piperine/ $\mathrm{g}$ black pepper powder, respectively. The effect of the independent variables $\mathrm{x}_{1}$ (ethanol concentration, \%), $\mathrm{x}_{2}$ (extraction time, hours) and $\mathrm{x}_{3}$ (drug to solvent ratio, $\mathrm{g} / \mathrm{ml}$ ) at three variation levels in the extraction process, is shown in Table 1 . Six replicates (runs 3,9,10,12,15 and 19) at the centre of the design were used to allow the estimation of a pure error sum of squares. In order to maximise the effects of unexplained variability in the observed responses due to extraneous factors the experiments were randomized. All experiments were carried out in a randomized order to minimize any effect of extraneous factors on the observed responses.

Table 1. Independent variable values of the process and their corresponding levels.

\begin{tabular}{|c|c|c|c|c|}
\hline \multirow{2}{*}{$\begin{array}{l}\text { independent } \\
\text { variable }\end{array}$} & \multirow{2}{*}{$\begin{array}{l}\text { symbol } \\
\text { coded }\end{array}$} & \multicolumn{3}{|c|}{ Levels } \\
\hline & & -1 & $\mathbf{0}$ & 1 \\
\hline $\begin{array}{l}\text { Ethanol } \\
\text { concentration (\%) }\end{array}$ & $\mathrm{X}_{1}$ & 10 & 50 & 90 \\
\hline $\begin{array}{l}\text { Extraction time } \\
\text { (hours) }\end{array}$ & $\mathrm{X}_{2}$ & 7 & 14 & 21 \\
\hline $\begin{array}{l}\text { Drug to solvent } \\
\text { ratio }(\mathrm{g} / \mathrm{ml})\end{array}$ & $X_{3}$ & $1: 10$ & $1: 20$ & $1: 30$ \\
\hline
\end{tabular}

The concentrations of $\mathrm{C}$ and $\mathrm{P}$ in $70 \%$ aqueous ethanol solution after the extraction experiments were determined with HPLC. Further investigations were made with these concentrations and if necessary with their suitable dilutions.

\section{Results and Discussion}

\subsection{Analyses of curcumin and piperine with} HPLC Results and Discussion

A single HPLC method for the simultaneously analysis of $\mathrm{C}$ and $\mathrm{P}$ was developed, with retention times of 6.2 minutes for $\mathrm{C}$ and 6.7 minutes for $\mathrm{P}$ (Figure 3 ).

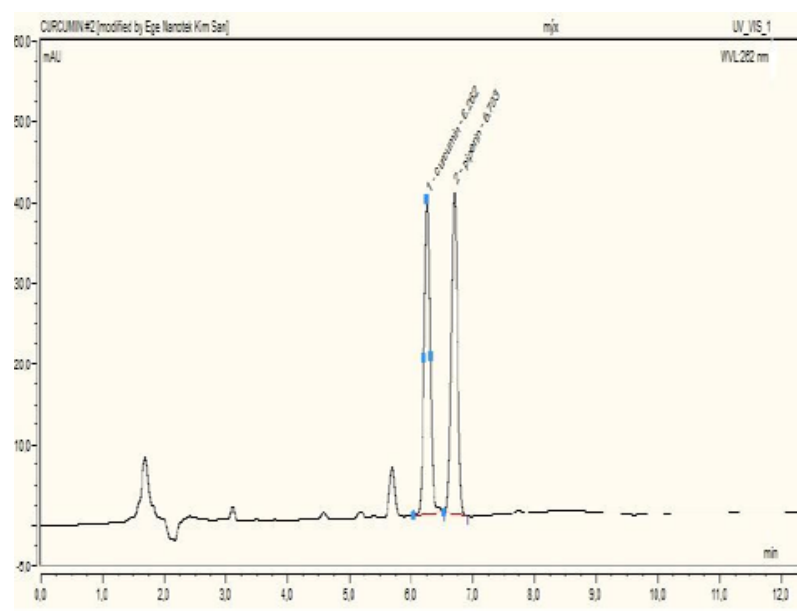

Figure 3. A chromatogram of curcumin and piperine obtained with HPLC.

\subsection{Extraction experiments for turmeric and black pepper}

The aim of the extraction experiments of turmeric and black pepper was to obtain a high yield of $\mathrm{C}$ and of $\mathrm{P}$, respectively. To show the main and interactive effects of the independent variables on the dependent one the 3D surface plots were drawn. The effects of ethanol concentration (10, 50 and $90 \%$ ) (Figure 4), extraction time (7, 14 and 21 hours) and drug to solvent ratio (1:10, $1: 20$ and $1: 30$ ) on the response expressed as yield are shown in Table 2 and 4 . The response surfaces based on these coefficients are shown in Figure 5 and 6 with one variable kept contant and varying the other two within the experimental range. In general, exploration of the response surfaces indicated a complex interaction between the variables.

The extraction experiments were interpretated with help of the MiniTab optimisation software using the RSM by performing the CCD.

Investigating the $\mathrm{C}$ and $\mathrm{P}$ yield results revealed the ideal conditions for their extraction as an extraction time of 15 hours, an ethanol concentration of $70 \%$ and a drug to solvent ratio of 1:20. 


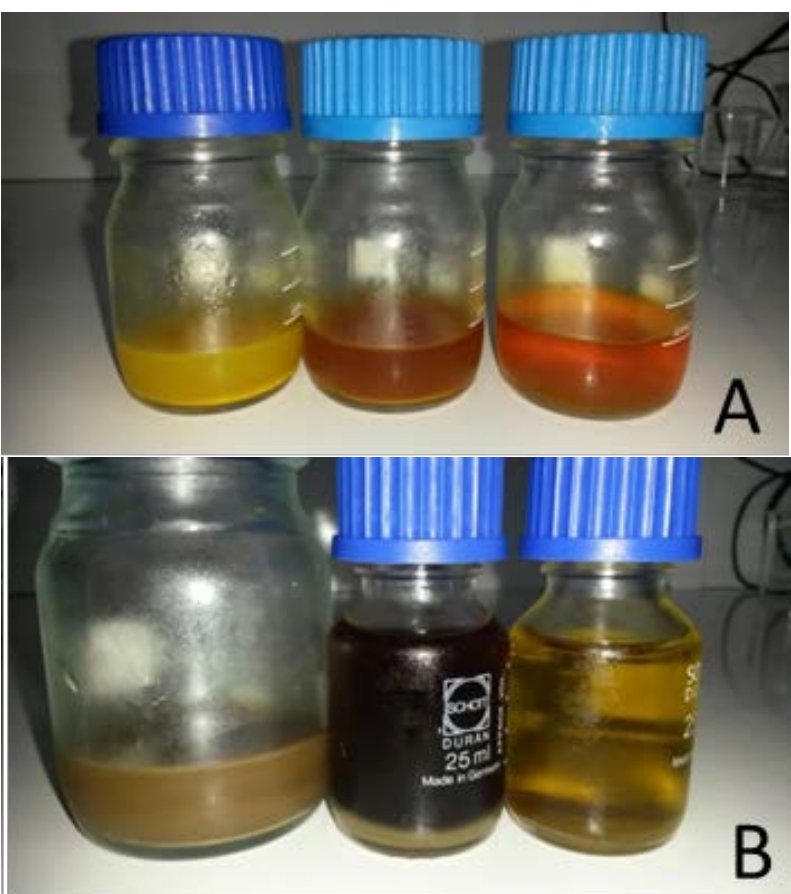

Figure 4. Images of turmeric (A) and of piperine (B) extracts with different ethanol concentrations (10, 50 and $90 \%)$.

Table 2. Experimental design and experimental results of the curcumin extraction from turmeric.

\begin{tabular}{|c|c|c|c|c|}
\hline $\begin{array}{c}\text { run } \\
\text { order }\end{array}$ & $\mathbf{X}_{\mathbf{1}}$ & $\mathbf{X}_{\mathbf{2}}$ & $\mathbf{X}_{\mathbf{3}}$ & $\begin{array}{c}\text { yield (mg curcumin/ } \\
\text { g turmeric powder) }\end{array}$ \\
\hline 1 & 10 & 7 & 30 & 0.0271 \\
\hline 2 & 90 & 7 & 10 & 6.8770 \\
\hline 3 & 50 & 14 & 20 & 2.6960 \\
\hline 4 & 10 & 14 & 20 & 0.0500 \\
\hline 5 & 90 & 21 & 30 & 4.5783 \\
\hline 6 & 50 & 14 & 10 & 0.7500 \\
\hline 7 & 10 & 7 & 10 & 0.0480 \\
\hline 8 & 10 & 21 & 30 & 0.0090 \\
\hline 9 & 50 & 14 & 20 & 2.6040 \\
\hline 10 & 50 & 14 & 20 & 2.3560 \\
\hline 11 & 50 & 14 & 30 & 2.8250 \\
\hline 12 & 50 & 14 & 20 & 2.4860 \\
\hline 13 & 50 & 21 & 20 & 5.9760 \\
\hline 14 & 10 & 21 & 10 & 0.0170 \\
\hline 15 & 50 & 14 & 20 & 2.3850 \\
\hline 16 & 90 & 7 & 30 & 9.0512 \\
\hline 17 & 90 & 14 & 20 & 4.8120 \\
\hline 18 & 50 & 7 & 20 & 6.2600 \\
\hline 19 & 50 & 14 & 20 & 2.6850 \\
\hline 20 & 90 & 21 & 10 & 7.1300 \\
\hline
\end{tabular}

$\mathrm{X}_{1}$ = ethanol concentration (\%); $\mathrm{X}_{2}=$ extraction time (hours); $\mathrm{X}_{3}=$ drug to solvent ratio $(\mathrm{g} / \mathrm{ml})$.

The obtained results of the $\mathrm{C}$ extraction from turmeric were statistically evaluated by variance analyses (Table 3).
Table 3. Variance analysis results of the curcumin extraction from turmeric.

\begin{tabular}{|c|c|c|c|c|c|}
\hline Source & DF & SS & MS & F & P \\
\hline $\mathrm{X}_{1}$ & 1 & 104.3112 & 104.3112 & 96.13 & 0.0003 \\
\hline $\mathrm{X}_{2}$ & 1 & 2.073 & 2.073 & 1.91 & 0.197 \\
\hline $\mathrm{X}_{3}$ & 1 & 0.278 & 0.278 & 0.26 & 0.623 \\
\hline $\mathrm{X}_{1} \mathrm{X}_{1}$ & 1 & 1.292 & 1.292 & 1.19 & 0.301 \\
\hline $\mathrm{X}_{2} \mathrm{X}_{2}$ & 1 & 24.772 & 24.772 & 22.83 & 0.001 \\
\hline $\mathrm{X}_{3} \mathrm{X}_{3}$ & 1 & 4.858 & 4.858 & 4.48 & 0.060 \\
\hline $\mathrm{X}_{1} \mathrm{X}_{2}$ & 1 & 2.174 & 2.174 & 2.00 & 0.187 \\
\hline $\mathrm{X}_{1} \mathrm{X}_{3}$ & 1 & 0.015 & 0.015 & 0.01 & 0.908 \\
\hline $\mathrm{X}_{2} \mathrm{X}_{3}$ & 1 & 2.777 & 2.777 & 2.56 & 0.141 \\
\hline Error & 10 & 10.851 & 1.085 & & \\
\hline Total & 19 & 147.890 & & & \\
\hline
\end{tabular}

$\mathrm{DF}=$ degrees of freedom; $\mathrm{SS}=$ sum of squares; $\mathrm{MS}=$ mean square; $\mathrm{F}$ $=\mathrm{F}$ value; $\mathrm{P}=\mathrm{P}$ value

The regression equation (Equation 1) of the curcumin yield, depending on several variables.

$$
\begin{aligned}
& \text { yield }=1+0.1518 X_{1}-1.519 X_{2}+0.672 X_{3}- \\
& 0.000429 X_{1} X_{1}+0.0613 X_{2} X_{2}-0.01329 X_{3} X_{3} \\
& -0.00186 X_{1} X_{2}-0.000109 X_{1} X_{3}-0.00842 X_{2} X_{3}
\end{aligned}
$$

(Equation 1)

The correlation coefficient $\mathrm{R}^{2}$ of the Equation 1 is 0.9266 . The extraction yield resulting from the turmeric extraction depending on several parameters is given in the 3 dimensional (Figure 5).

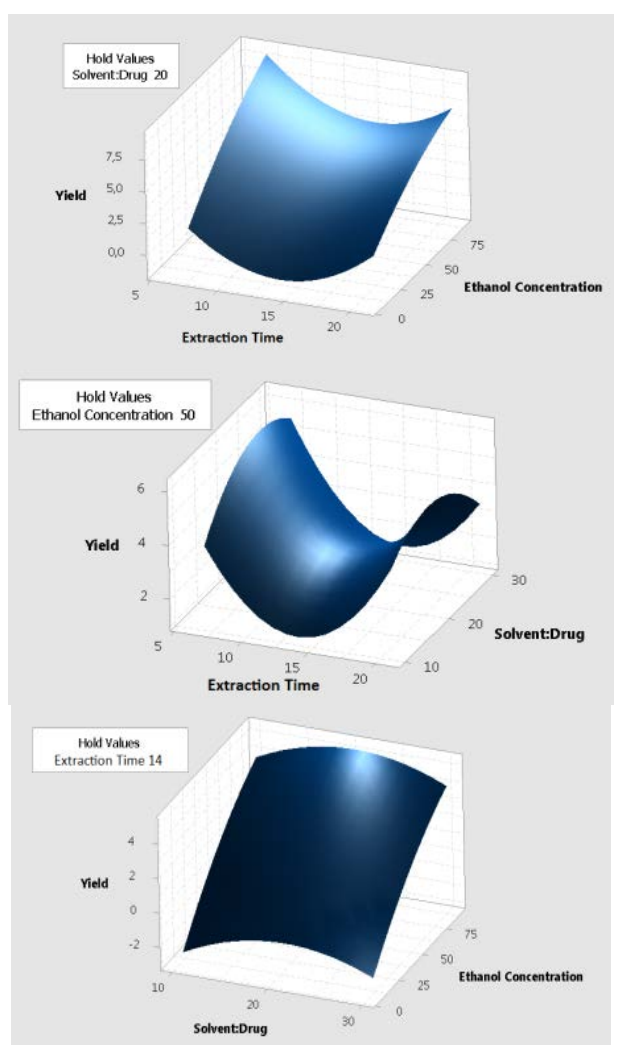

Figure 5. Variation of curcumin yield depending on extraction time and ethanol concentration (a), extraction time and drug:solvant relation (b) and drug:solvant relation and ethanol concentration (c). 
Table 4. The experimental design and the experimental results of the piperine extraction from black pepper.

\begin{tabular}{|c|c|c|c|c|}
\hline $\begin{array}{c}\text { run } \\
\text { order }\end{array}$ & $\mathbf{X}_{\mathbf{1}}$ & $\mathbf{X}_{\mathbf{2}}$ & $\mathbf{X}_{\mathbf{3}}$ & $\begin{array}{c}\text { yield (mg piperine/ } \mathbf{g} \\
\text { blackpepper powder) }\end{array}$ \\
\hline 1 & 10 & 7 & 30 & 0.018 \\
\hline 2 & 90 & 7 & 10 & 22.605 \\
\hline 3 & 50 & 14 & 20 & 21.336 \\
\hline 4 & 10 & 14 & 20 & 0.010 \\
\hline 5 & 90 & 21 & 30 & 23.557 \\
\hline 6 & 50 & 14 & 10 & 13.266 \\
\hline 7 & 10 & 7 & 10 & 0.053 \\
\hline 8 & 10 & 21 & 30 & 0.370 \\
\hline 9 & 50 & 14 & 20 & 22.242 \\
\hline 10 & 50 & 14 & 20 & 19.734 \\
\hline 11 & 50 & 14 & 30 & 21.437 \\
\hline 12 & 50 & 14 & 20 & 19.998 \\
\hline 13 & 50 & 21 & 20 & 18.658 \\
\hline 14 & 10 & 21 & 10 & 0.023 \\
\hline 15 & 50 & 14 & 20 & 20.210 \\
\hline 16 & 90 & 7 & 30 & 27.798 \\
\hline 17 & 90 & 14 & 20 & 23.738 \\
\hline 18 & 50 & 7 & 20 & 22.572 \\
\hline 19 & 50 & 14 & 20 & 20.048 \\
\hline 20 & 90 & 21 & 10 & 21.362 \\
\hline
\end{tabular}

$\mathrm{X}_{1}=$ ethanol concentration (\%); $\mathrm{X}_{2}=$ extraction time (hours); $\mathrm{X}_{3}=$ drug to solvent ratio $(\mathrm{g} / \mathrm{ml})$.

The obtained results of the $\mathrm{P}$ extraction from black pepper were statistically evaluated by variance analyses (Table 5)

Table 5. Variance analysis results of the piperine extraction from black pepper.

\begin{tabular}{|c|c|c|c|c|c|}
\hline Source & DF & SS & MS & F & P \\
\hline $\mathrm{X}_{1}$ & 1 & 1406.26 & 1406.26 & 478.18 & $<0.001$ \\
\hline $\mathrm{X}_{2}$ & 1 & 8.24 & 8.24 & 2.80 & 0.125 \\
\hline $\mathrm{X}_{3}$ & 1 & 25.19 & 25.19 & 8.57 & 0.015 \\
\hline $\mathrm{X}_{1} \mathrm{X}_{1}$ & 1 & 155.21 & 155.21 & 52.78 & $<0.001$ \\
\hline $\mathrm{X}_{2} \mathrm{X}_{2}$ & 1 & 4.15 & 4.15 & 1.41 & 0.262 \\
\hline $\mathrm{X}_{3} \mathrm{X}_{3}$ & 1 & 11.39 & 11.39 & 3.87 & 0.077 \\
\hline $\mathrm{X}_{1} \mathrm{X}_{2}$ & 1 & 4.21 & 4.21 & 1.43 & 0.259 \\
\hline $\mathrm{X}_{1} \mathrm{X}_{3}$ & 1 & 6.26 & 6.26 & 2.13 & 0.175 \\
\hline $\mathrm{X}_{2} \mathrm{X}_{3}$ & 1 & 0.86 & 0.86 & 0.29 & 0.601 \\
\hline Error & 10 & 29.41 & 29.41 & & \\
\hline Total & 19 & 1812.25 & 1812.25 & & \\
\hline
\end{tabular}

$\mathrm{DF}=$ degrees of freedom; $\mathrm{SS}$ = sum of squares; $\mathrm{MS}$ = mean square; F $=\mathrm{F}$ value $\mathrm{P}=\mathrm{P}$ value

The regression equation (Equation 2) of the curcumin yield, depending on several variables.

$$
\begin{gathered}
\text { yield }=-11.95+0.7581 X_{1}-0.609 X_{2}+0.928 X_{3}- \\
0.004695 X_{1} X_{1}+0.0251 X_{2} X_{2}-0.0204 X_{3} X_{3} \\
-0.00259 X_{1} X_{2}+0.00221 X_{1} X_{3}-0.00467 X_{2} X_{3}
\end{gathered}
$$

The correlation coefficient $\mathrm{R}^{2}$ of the equation 2 is 0.9838 .

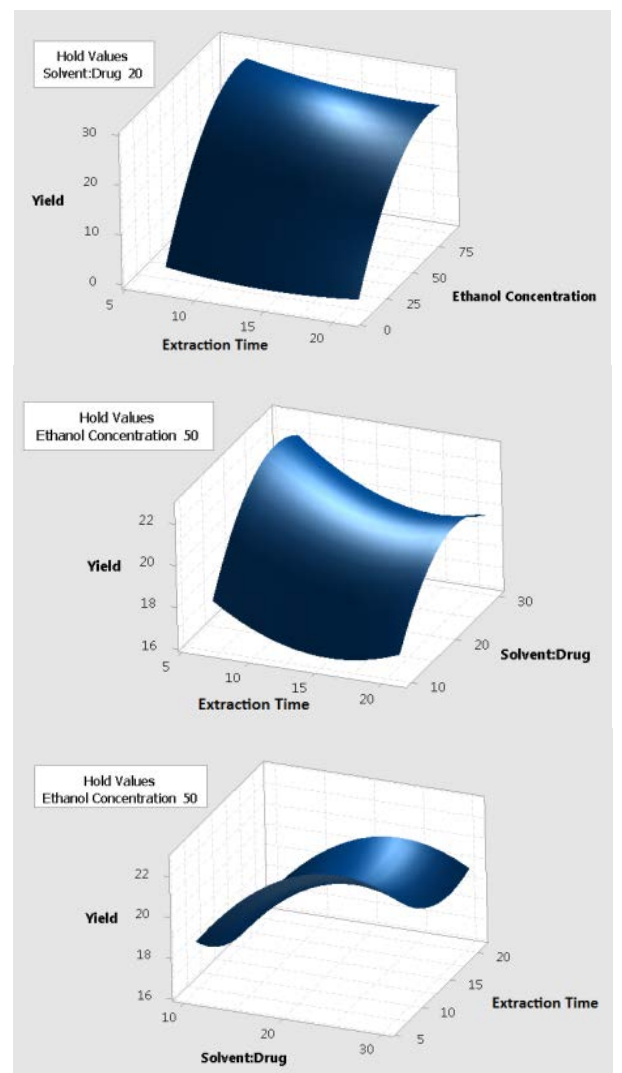

Figure 6. Variation of black pepper yield depending on extraction time and ethanol concentration (a), extraction time and drug:solvant relation (b) and drug:solvant relation and ethanol concentration (c).

Investigating the yield results of the extraction experiments of $\mathrm{C}$ from turmeric (Figure 5) and of $\mathrm{P}$ from black pepper (Figure 6) revealed that after an extraction time of 15 hours no further improvement was determined. The experimental design analysis showed that the variables affecting the extraction yield are the ethanol concentration and drug to solvent ratio. The ideal parameter for obtaining a high yield from the extractions were an extraction time of 15 hours, an ethanol concentration of $70 \%(\mathrm{v} / \mathrm{v})$ and a drug to solvent ratio of $1: 20$.

The concentrations of $\mathrm{C}$ and $\mathrm{P}$ in $70 \%$ aqueous ethanol after the extraction experiments were determined as 0.49 and $1.21 \mathrm{mg} / \mathrm{ml}$, respectively.

\section{Conclusion}

In this study, the optimum parameters for the conventional extraction of $\mathrm{C}$ from turmeric and $\mathrm{P}$ from black pepper were successfuly determined in order to achieve high yields.

For that purpose a HPLC method was successfully developed for the simultaneously analysis of $\mathrm{C}$ and $\mathrm{P}$. Several parameters such as, different extraction times, ethanol concentrations and drug to solvent ratios were ivestigated with help of RSM, it was possible to extract $\mathrm{C}$ from trumeric and $\mathrm{P}$ from black pepper at high yields. 
The ideal parameter for this conventional extraction of $\mathrm{C}$ from turmeric and of $\mathrm{P}$ from black pepper, respectively, were the extraction time of 15 hours, ethanol concentration of $70 \%(\mathrm{v} / \mathrm{v})$ and drug to solvent ratio of $1: 20$.

The concentrations of $\mathrm{C}$ and $\mathrm{P}$ in $70 \%$ aqueous ethanol after the extraction experiments were determined as 0.49 $\mathrm{mg} / \mathrm{ml}$ and $1.21 \mathrm{mg} / \mathrm{ml}$ with HPLC, respectively.

\section{References}

1. Kingston, D. G. I. Modern natural products drug discovery and its relevance to biodiversity conservation. Journal of Natural Products, 2011; 74, $496-511$.

2. Jayaprakasha, G. K.; Jaganmohan Rao, L.; Sakariah, K. K Antioxidant activities of curcumin, demethoxycurcumin and bisdemethoxycurcumin. Food Chemistry, 2006; 98, 720-724.

3. Sreejayan; Rao; M. N. A. Nitric oxide scavenging by curcuminoids. Journal of Pharmacy and Pharmacology, 1997; 49, 105107.

4. Villegas, I.; Sanchez-Fidalgo, S.;, de la Lastra, C. A. New mechanisms and therapeutic potential of curcumin for colorectal cancer. Molecular Nutrition \& Food Research. 2008; 52, 1040-1061.

5. Yoysungnoen, P.; Wirachwong, P.; Changtam, C.; Suksamram, A., Patumraj, S. Anti-cancer and anti-angiogenic effects of curcumin and tetrahydrocurcumin on implanted hepatocellular carcinoma in nude mice, World Journal of Gastroenterology WJG. 2008; 14, 2003-2009.

6. Ammon, H. P. T.; Wahl, M. A. Pharmacology of curcuma-longa. Planta Medica, 1991; 57, 1-7.

7. Jurenka, J. S. Anti-inflammatory properties of curcumin, a major constituent of curcuma longa: a review of preclinical and clinical research. Alternative Medicine Review, 2009; 14, 141-153.

8. Kim, M. K.; Choi, G. J.; Lee, H. S.Fungicidal property of Curcuma longa l. Rhizome-derived curcumin against phytopathogenic fungi in a greenhouse. Journal of Agricultural and Food Chemistry, 2003; 51, 1578-1581.

9. Wang, Y.; Lu, Z. X.; Wu, H.; Lv, F. X. Study on the antibiotic activity of microcapsule curcumin against foodborne pathogens. International Journal of Food Microbiology, 2009; 136, 71-74.

10. Yang, K.; Lin, L.; Tseng, T.; Wang, S.; Tsai, T. Oral bioavailability of curcumin in rat and the herbal analysis from Curcuma longa by LCMS/MS. Journal of Chromatography B 2007; 853, 183-9.

11. Shaikh, J.; Ankola, D.D.; Beniwal, V.; Singh, D.; Ravi Kumar, M.N.V. Nanoparticle encapsulation improves oral bioavailability ofcurcumin by at least 9-times when compared to curcuminadministered with piperine as absorption enhancer. European Journal of Pharmaceutical Sciences, 2009; 37, 223-30.

12. Tonnesen, H. H. Solubility, chemical and photochemical stability of curcumin in surfactant solutions e studies of curcumin and curcuminolds. Pharmazie 2002; 57, 820-824.

13. Shoba, G.; Joy, D.; Joseph, T.; Majeed, M.; Rajendran, R.; Srinivas, P.S.S.R. Influence of piperine on the pharmacokinetics of curcumin in animals and human volunteers. Planta Medica. 1998; 64, 353-6.

14. Han, Y.; Chin Tan, T.M.; Lim L.-Y. In vitro and in vivo evaluation of theeffects of piperine on P-gp function and expression. Toxicology and Applied Pharmacology, 2008; 230, 283-9.
15. Wahlang, B.; Pawar, Y.B.; Bansal, A.K. Identification of permeability-related hurdles in oral delivery of curcumin using the Caco-2 cell model. European Journal of Pharmaceutics and Biopharmaceutics, 2011;77, 275-82.

16. Navickiene, H.M.D.; Alecio, A.C.; Kato, M.J.; Bolzani, V.S.; Young, M.C.M.; Cavalheiro, A.J.; Furlan, M. Antifungal amides from Piper hispidum and Piper tuberculatum, Phytochemistry, 2000; 55, 621 $-626$.

17. Bajad,S.; Bedi, K. L.; Singla, A. K.; Johri, R. K. Antidiarrhoeal activity of piperine in mice. Planta Medica, 2001; 67, 284 - 287

18. Mujumdar, A.M.; Dhuley, J.M.; Deshmukh, V.; Raman, P.H.; Naik, S.R.; Anti-inflammatory activity of piperine. Japanese Journal of Medical Science \& Biology, 1990; 43, 95 - 100.

19. Stohr, J.R.; Xiao, P.G.; Bauer, R. Constituents of Chinese Piper species and their inhibitory activity on prostaglandin and leukotriene biosynthesis in vitro. Journal of Ethnopharmacol. 2001; 75, 133 - 139.

20. Zaugg, J.; Baburin, I.; Strommer, B.; Kim, H.-J.; Hering, S.; HPLC-based activity profiling: discovery of piperine as a positive GABA(A) receptor modulator targeting a benzodiazepine-independent binding site. Hamburger, M. Journal of Natural Products, 2010; 73, 185-191.

21. Hering, S.; Erker, T.; Schwarz, T.; Baburin, I.; Schellmann, D. Novel piperine derivatives as gaba - a receptors modulators, WO2011080313A1, 2011

22. Khajuria, A.; Zutshi, U.; Bedi, K.L. Permeability characteristics ofpiperine on oral absorption - an active alkaloid from peppersand a bioavailability enhancer. Indian Journal of Experimental Biology, 1998; 36, 46-50.

23. Okura, T.; Ibe, M.; Umegaki, K.; Shinozuka, K., Yamada, S. Effects ofdietary ingredients on function and expression of Pglycoprotein in human intestinal epithelial cells. Biological \& Pharmaceutical Bulletin, 2010; 33, 255-9.

24. Velpandian, T.; Jasuja, R.; Bhardwaj, R.K.; Jaiswal, J.; Gupta, S.K. Piperine in food: interference in the pharmacokinetics of phenytoin. European Journal of Drug Metabolism and Pharmacokinetics, 2001; 26, 241-247.

25. Zutshi, R.K.; Singh, R.; Zutshi, U.; Johri, R.K.; Atal, C.K. Influence of piperine on rifampicin blood levels in patients of pulmonary tuberculosis. Journal of Association of Physicians of India JAPI, 1985; 33, 223-224.

26. Schuetz, E.G.; Schinkel, A.H.; Relling, M.V.; Schuetz, J.D. Pglycoprotein: a major determinant of rifampicin-inducible expression of cytochrome P4503A in mice and humans. Proceedings of the National Academy of Sciences of the United States of America 1996; 93, 4001-4005.

27. Schinkel, A.H.; Wagenaar, E.; Mol, C.A.; van Deemter, L. Pglycoprotein in the blood-brain barrier of mice influences the brain penetration and pharmacological activity of many drugs. Journal of Clinical Investigation. 1996; 97, 2517-2524.

28. Bhardwaj, R.K.; Glaeser, H.; Becquemont, L.; Klotz, U.; Gupta, S.K.; Fromm, M.F. Piperine, a major constituent of black pepper, inhibits human P-glycoprotein and CYP3A4, Journal of Pharmacology and Experimental Therapeutics. 2002; 302, 645-650.

29. Vogel, H.; Pelletier, J. Curcumin-biological and medicinal properties, Journal of Pharmacology, 1815; 2, 50.

30. Nabati, M.; Mahkam, M.; Heidari, $\mathrm{H}$. Isolation and characterization of curcuminfrom powdered rhizomes of turmeric plant 
marketed in Maragheh city of Iranwith soxhlet technique, Iranian Chemical Communication, 2014; 2, 236-243.

31. Mandal, V.; Mohan,Y.; Hemalatha, S. Microwave assisted extraction ofcurcumin by sample-solvent dual heating mechanism using Taguchi L 9orthogonal design, Journal of Pharmaceutical and Biomedical Analysis, 2008; 46, 322-327.

32. Wakte, P.; Sachin, B.; Patil, A.; Mohato, D.; Band, T.; Shinde, D. Optimization ofmicrowave, ultra-sonic and supercritical carbon dioxide assisted extractiontechniques for curcumin from Curcuma longa, Separation and Purification Technology, 2011; 79, 50-55.

33. Euterpio, M.A.; Cavaliere, C.; Capriotti, A.L.; Crescenzi, C. Extending theapplicability of pressurized hot water extraction to compounds exhibitinglimited water solubility by $\mathrm{pH}$ control: curcumin from the turmeric rhizome, Analytical and Bioanalytical Chemistry, 2011; 401, 2977-2985.

34. Kurmudle, N.; Kagliwal, L D.; Bankar, S B.; Singhal, R.S. Enzyme-assistedextraction for enhanced yields of turmeric oleoresin and its constituents, Food Bioscience. 2013; 3, 36-41.

35. Kiamahalleh, M.V.; Najafpour-Darzi, G.; Rahimnejada, M.; Moghadamnia, A.A.; Kiamahalleh, M.V. High performance curcumin subcritical water extraction fromturmeric (Curcuma longa L.). Journal of Chromatograph B, 2016; 1022, 191-198.

36. Sogi, D. S.; Sharma S.; Oberoi D. P. S.; Wani I. A. Effect of extraction parameters on curcumin yield from Turmeric. Journal of Food and Science Technology, 2010; 47(3), 300-304.

37. Priyadarsini, K.I. The Chemistry of Curcumin: From Extraction to Therapeutic Agent. Molecules, 2014; 12, 20091-20112.

38. Shen, L.; Ji, H. -F. The pharmacology of curcumin: Is it the degradation products? Trends in Molecular Medicine, 2012; 18, 138144 .

39. Wang, Y. J.; Pan, M. H.; Cheng, A. L.; Lin, L. I.; Ho, Y. S.; Hsieh, C.Y.; Lin, J. K. Stability of curcumin in buffer solutions and characterization of its degradation products, Journal of Pharmaceutical and Biomedical Analysis, 1997; 15, 1867-1876.

40. Bener, M.; Özyürek, M.; Güçlü, K.; Apak, R. Optimization of Microwave-Assisted Extraction of Curcumin from Curcuma longa L. (Turmeric) and Evaluation of Antioxidant Activity in Multi-Test Systems. Records of Natural Products 2016; 10:5, 542-554.

41. Kowsalya, R.; Krishnaveni, M. Extraction and Antibacterial Studies of Curcumin. Journal of Pure ad Applied Microbiology, 2011; 5, 217-321.

42. Avram, M., Stroescu, M.; Stoica-Guzun, A.; Floarea, O.; Dobre, T. Optimization of Curcumin Extraction from Turmeric Powder using a Box-Behnken Design (BBD). Revista de chimie, 2015; 66, 79-82.
43. Marion, L. Alkaloids - Chemistry and Physiology, Academic Press, New York, 1960, 31 pp.

44. Staudinger, H.; Schneider, H: Ber. Ketene, eine neue Körperklasse. Dtsch. Chem. Ges. B 1923, 56B, 699 - 711.

45. Ressmann, A.K.; Zirbs, R.; Pressler, M.; Gaertner, P.; Bica, K. Surface-active Ionic Liquids for Micellar Extraction of Piperine from Black Pepper. Zeitschrift für Naturforschung, 2013; 68b, 1129 - 1137.

46. Basile, A.; Clifford, A. A.; Jimnez-Carmona, M. Extraction of Rosemary by Superheated Water. Journal of Agricultural and Food Chemistry, 1998, 46, 5205-5209.

47. Vidal, J. P.; Richard, H. Production of Black Pepper Oleoresin by Dense Carbon dioxide or Carbon dioxide-Ethanol Extraction. Sciences des aliments, 1987, 7 (3), 481-498.

48. Hans, J. Extraction of Organic Constituents from Solids. German offen. DE 3,706,594, 1987; Chemical Abstracts, 1987, 109, P172901e.

49. Raman, G.; Gaikar, V.G. Microwave-Assisted Extraction of Piperine from Piper nigrum, Industrial \& Engineering Chemistry Research, 2002; 41, 2521-2528.

50. Raman, G.; Gaikar, V.G. Extraction of Piperine from Piper nigrum (Black Pepper) by Hydrotropic Solubilization, Industrial \& engineering chemistry research, 2002; 41, 2966-2976.

51. Padalkar, KV.; Gaikar, V.G. (2008) Extraction of Piperine from Piper Nigrum (Black Pepper) by Aqueous Solutions of Surfactant and Surfactant + Hydrotrope Mixtures. Separation Science and Technology, 2008; 43, 3097-3118.

52. Triveni, R.; Shamala, T. R.; Rastogi, N. K. Optimised production and utilization of exopolysaccharide from Agrobacterium radiobacter. Process Biochemistry, 2001; 36, 787-795.

53. Kalaimahan, T.; Tapobrata, P. Application of response surface methodology to evaluate the influence of temperature and initial $\mathrm{pH}$ on the production of b-1,3-glucanase and carboxymethylcellulase from Trichoderma hzrzianum. Enzyme and Microbial Technology, 1995; 11, 1043-1049.

54. Moorthi, C.; Kumar, C.S.; Mohan, S.; Krishnan, K.; Kathiresan, K. Application of validated RP-HPLC-PDA method for the simultaneous estimation of curcumin and piperine in Eudragit E 100 nanoparticles. Journal of Pharmacy Research, 2013; 7, 224-229.

55. Firatligil-Durmus, E.; Evranuz, O. Response surface methodology for protein extraction optimization of red pepper seed (Capsicum frutescens). LWT - Food Science and Technology, 2010; 43, 226-231.

56. Quanhong, L.; Caili, F. Application of response surface methodology for extraction optimization of germinant pumpkin seeds protein. Food Chemistry, 2005; 92, 701-706. 